\begin{tabular}{c|c|c}
\hline \hline & CLIMATE RESEARCH \\
Vol. 26: 43-59, 2004 & Clim Res & Published April 19 \\
\hline
\end{tabular}

\title{
Public perceptions of unusually warm weather in the UK: impacts, responses and adaptations
}

\author{
J. P. Palutikof*, M. D. Agnew, M. R. Hoar \\ Climatic Research Unit, School of Environmental Sciences, University of East Anglia, Norwich NR4 7TJ, UK
}

\begin{abstract}
Evidence of socio-economic sensitivity to climate variability is accumulating and is largely based on modelling studies. This paper examines the impacts of climate extremes (unusually hot summers and unusually warm winters) from the perspective of the perception of the general public. Postal surveys were conducted for 2 regions in the UK: (1) southern England and (2) central and southern Scotland. Information was gathered regarding attitudes to warm climate anomalies, the perceived risks and benefits of recent extremes, and the perceived potential risks and benefits of such anomalies becoming more common in the future. The impacts of climate extremes were assessed with regard to (1) the individual's 'everyday life' and (2) the national 'good'. The responses indicate a high level of awareness of the impacts of climate extremes and deep concerns about global warming tempered by an appreciation that there is potential for both positive and negative outcomes. For several issues, the perception of respondents from Scotland and England differed significantly. In particular, more English than Scottish residents judge unusually warm summers as having a severe negative impact on agriculture and air quality than do Scottish residents. We suggest that regional differences in climate could at least in part explain the apparent geographic differences in response. The results indicate both short-term and long-term adaptive and behavioural responses to a season of exceptional warmth and a willingness to implement further lifestyle adjustments for a hypothetical future in which such events become more common.
\end{abstract}

KEY WORDS: Climate extremes · Perception survey $\cdot$ Impacts · Adaptation Resale or republication not permitted without written consent of the publisher

\section{INTRODUCTION}

The potential impacts of climate change on human activity have been widely studied (e.g. CCIRG 1996, IPCC 1998, 2001, National Assessment Synthesis Team 2000) and, increasingly, attention is turning to the role of adaptation strategies in averting and minimising these impacts (e.g. Parry 2000, Hulme et al. 2002). The majority of impact studies take a deterministic approach, basing their conclusions on the present-day relationships between climatic variability and, for example, agriculture (Downing et al. 1999), health (McMichael et al. 1996) and water resources (Arnell 1996). These relationships may be used to construct an impacts model which can then be perturbed in some manner, for example, using the output from climate- model simulations of the future, to represent the effects of climate change (Kramer et al. 1996, Martens 1998).

However, a proper understanding of climate change impacts, and even more so of the potential for human adaptation, can only be achieved through knowledge of the attitudes of people, in their roles both as audience, experiencing the impacts, and as actors, with the potential to implement adaptive strategies. Attitudes can be explored in a number of ways, for example, through focus groups (Darier et al. 1998) and through face-to-face interviews (Schellnhuber et al. 1994). Focus groups bring together small groups of people in an environment of in-depth discussion and participation. Stoll-Kleemann et al. (2001) used this approach to explore attitudes to climate change. They are dynamic - the responses by the participants at the end 
of the discussion may have evolved to be different from the responses expressed at the beginning. Face-toface interviews, although essentially static, are high cost, which may limit their application. They are a useful tool to explore management and professional attitudes to impacts and adaptation. For example, Subak (2000) looked at perceptions and activities related to climate change amongst water industry managers in the UK. They can also be used with the general public and are especially useful with respondents who lack literacy skills. They were used in a 6-nation (Canada, USA, Mexico, Brazil, Portugal and Russia) survey of the lay public exploring perceptions of global warming reported by Dunlap (1998). A step further is the ethnographic face-to-face interview, which uses open-ended questions, follow-up probes for topics raised by informants, and paraphrases for verification (Kempton 1991a,b, 1997). Such surveys require highly skilled interviewers, and hence they tend to be small: in the case of the survey reported by Kempton (1991b), just 14 interviews were carried out. Here, we employ a third way, the use of a postal questionnaire to explore the perceptions of the general public to climatic variability and change, the impacts and likely adaptation strategies. This approach obviously cannot be as indepth as focus groups. However, it has the advantage of accessing a larger potential sample. The questionnaire is designed in advance, so that everyone is responding to the same questions, and is static. This greatly facilitates processing of the responses to arrive at quantitatively expressed results.

There is a rapidly growing body of empirical studies on perceptions of climate change, and these are reviewed in Section 1.1 below. What is perhaps unique about this study is the emphasis on responsive behaviour and adaptation. The questionnaire begins by exploring awareness of and experience with short-term climate extremes of the present day. This first section is then used as a springboard to ask people to think about future climate change, what the impacts on their everyday life are likely to be, and in what ways (and to what extent) they would modify their behaviour, through choice or necessity, in order to adapt to and possibly mitigate the impacts. Respondents are then asked to consider impacts at the national scale, with respect to the national 'good'. Several activity sectors are explored, including natural ecosystems, agriculture, transport, health and energy. An attempt is made to rank the perceived importance of the impacts in the different sectors. This survey breaks new ground in that it explores how people modified their behaviour in response to past extremes, both in the short term and the longer term, and how they think their behaviour might change if such extremes became more common in future (i.e. under conditions of climate change).

\subsection{Previous perception studies}

A possible 4-fold classification of previous studies undertaken to assess public perceptions of climate change is as follows:

- comparative studies of perceptions of issues of great public concern, of which climate change is one;

- cross-national and cross-cultural studies of perceptions of climate change;

- explorations of the extent, nature and causes of public misconceptions surrounding climate change; and

- examinations of the extent to which people are prepared to take action to mitigate climate change, and the factors determining their views.

Below, we briefly consider the literature on public perceptions of climate change within this framework. Of course, papers contribute insights in more than one category, but still the framework represents a useful basis for discussion and helps to locate this study in the growing body of empirical studies.

When compared to other environmental issues, global warming and climate change are not seen as immediate or pressing risks. Immerwahr (www.agu.org/ sci_soc/attitude_study.html), in a question about the relative importance of a range of environmental issues, found that global warming scored low in comparison to concerns about air, soil and water pollution, and the ozone hole. The general attitude appears to be that climate change is 'a legitimate though less than urgent issue' (Seacrest et al. 2000). O'Connor et al. (1998) explored public views on the mitigation of a range of societal concerns including violent crime, pollution, heart disease, AIDS and climate change. People had only moderate faith in the ability of government to address climate change, and they had low faith in more government spending devoted to this issue.

Studies have been performed to explore whether people from different cultures and/or nations perceive the risk surrounding climate change in different ways, whether quantitatively or qualitatively. Dunlap (1998), reporting a 6-nation study, found broadly consistent views towards global warming, with respondents ranking its relative importance below that of ozone depletion or rainforest destruction, and acknowledging their poor understanding of the subject. The majority of respondents in all countries except Russia believed that global warming is already occurring. Perron et al. (2001) compared the views of leaders of green groups in Canada and Costa Rica, but failed to find convincing evidence of cognitive solidarity in the green movement concerning climate change. Respondents in the cross-national study by Bord et al. (1998) also considered global warming not to be a 'front-burner' issue and, whilst supporting mitigation initiatives that would not levy 
unusual hardships, were unwilling to alter their lifestyle. Harrison et al. (1996) made a comparative study of public perceptions in the UK and The Netherlands of a range of environmental issues including global warming, and they found environmental awareness to be generally higher in The Netherlands. However, Rudig (1995) working with respondents in the same countries, and addressing global warming specifically, found greater concern in the UK than in The Netherlands.

People feel that they improperly understand the science underlying global warming. Common misconceptions include confusion with ozone depletion, inflated estimates of temperature change, and a belief that all environmentally harmful acts cause climate change (Gowda et al. 1997). Educational institutions (Seacrest et al. 2000), the media (González \& da Silveira 1997), and interpersonal communication (Stamm et al. 2000) have an important role to play in correcting these misconceptions. However, Gowda et al. (1997) questioned high-school students about attitudes towards and knowledge of global warming, and they concluded that reliance on televised news media, amongst other factors, contributed to a poor understanding. They found a high level of trust in teachers and scientists, suggesting an important role for scientists as well as educators in correcting popular misconceptions about global warming. Krosnick et al. (2000) looked at public interest in global warming before and after the 1997 campaign by President Clinton to build support for the Kyoto Treaty. Although the debate produced almost no change in overall public opinion when political affiliations were taken into account, strong Democrats were much more likely to endorse the Clinton Administration position than strong Republicans. Ungar (2000) sought explanations for the relative success of the ozone depletion issue in engendering public understanding and concern by comparison with global warming. Whilst the former encouraged the acquisition of knowledge and provided a sense of immediate and concrete risk, the latter failed on both these counts and 'remains in a public limbo'.

Finally, there are the set of studies which look at personal willingness to take mitigation actions. These emphasise the importance of understanding the causes of climate change and the likely impacts as predictors of willingness to take action and support for government action (O'Connor et al. 1999, Bord et al. 2000). Stoll-Kleemann et al. (2001) showed, using focus groups, how people erect psychological barriers to justify why they should not act individually or collectively to mitigate climate change. They suggest the use of tailored packages of information and community-based policy incentives to overcome these barriers.
A number of common threads emerge from these studies, revealing that people have:

- a lack of proper understanding of the underlying causes of global warming;

- a sense that global warming is not a 'front-burner' problem in comparison to issues such as ozone depletion and toxic wastes; and

- the attitude that measures to combat global warming are the responsibility of governments rather than individuals (Schellnhuber et al. 1994), and an unwillingness to change lifestyles to address the problem.

None of these studies addressed people's responses and adaptations to warmer conditions, whether present-day seasonal extremes or a possible warmer future due to climate change. Indeed, we found only one reference to adaptation, and that only in the very broadest terms. Kempton (1991b) asked whether adaptation was a reasonable strategy and received very negative responses from all but one respondent. The study presented here is unique in exploring in detail how people react to warmer seasonal extremes, both summer and winter, and in asking people to think about how their behaviour might change in the future if such conditions were to become more common.

\subsection{Recent UK weather extremes}

In this paper, our approach is to ask people to think about their responses to recent exceptional seasons, specifically unusually hot dry summers and warm winters, and to use those thoughts as a springboard to explore their hypothetical responses to a climate future in which such extremes become more common. To introduce the questions related to past experience, we asked the respondents to recall a recent, unusually hot dry summer and an exceptionally mild winter.

In the UK, the most recent period of exceptional warmth at the time the questionnaire was administered was the 12 mo period between November 1994 and October 1995, within which the months of July and August 1995 were the warmest on record; the central England temperature for these months was $3^{\circ} \mathrm{C}$ warmer than the 1961-1990 average (Hulme 1997, Jones \& Conway 1997). The questionnaire was sent out in September/October 1998. We believed that the gap of $3 \mathrm{yr}$ was sufficiently small that people would recall 1995 as their most recent experience of a hot summer. In fact, as is shown below, this was a rather optimistic belief.

The mild winter of 1989/1990 and the warm summers of 1989 and 1990 (Cannell \& Pitcairn 1993) contributed to heightened UK media interest in global warming in the early 1990s. The 12 mo period end- 
ing June 1990 was almost $2{ }^{\circ} \mathrm{C}$ warmer than the 1961-1990 central England average, with the highest positive anomalies occurring in south-east England (Brugge 1992). This latitudinal gradient in the intensity of extreme events has followed a similar pattern in recent decades. The unusual dryness of 1995 was more extreme in England and Wales than in Scotland. Between April and August 1995, England and Wales received $155 \mathrm{~mm}$ of rainfall (47\% of the 1961-1990 average) compared to $332 \mathrm{~mm}$ of rainfall (72\% of the 1961-1990 average) received in Scotland (Marsh \& Turton 1996). Mid- and east Kent (southeast England) went without rain for $42 \mathrm{~d}$ between mid July and late August 1995 (Dukes \& Eden 1997).

Only $10 \%$ of the respondents identified 1995 as the recalled hot summer in the survey; $20 \%$ identified 1997, 9\% identified 1996 and 33\% could not remember (the remainder identified yet another date, or failed to answer this question). With regard to 1996 these recollections were incorrect, since the year was slightly cooler than the 1961-1990 average. The year 1997 was the third warmest in the 340 yr central England temperature series, and 14 'hot' days (defined as a daily mean temperature above $20^{\circ} \mathrm{C}$ ) were recorded (Hulme 1999a). However, the summer of 1995 recorded 26 hot days, the largest number in the twentieth century. This lack of precise recall reflects an inability to remember the climate of specific years but not necessarily an inability to recall an event per se and should not therefore compromise the survey results.

Table 1. Annual rainfall, 1961-1990 average (National Statistics 2001, Table 11.2)

\begin{tabular}{|lc|}
\hline Area & $\mathrm{mm}$ \\
\hline Scotland & 1437 \\
England & 823 \\
English regions & \\
Anglian & 596 \\
Thames & 689 \\
Southern & 779 \\
Wessex & 838 \\
\hline
\end{tabular}

\subsection{The questionnaire}

In the questionnaire, we sought to better understand how the general public:

- experience periods of unusually warm weather in their everyday life,

- perceive nationwide impacts of recent seasonal extremes,

- modify their short- and long-term behaviour as a result of such extremes, with respect to both voluntary additional responses (for example, taking more short holidays) and adaptation (for example, changing to low water-use garden-planting schemes), and

- perceive they would be affected by a greater frequency of such extreme events in the future.

Drafts were prepared and tested on University of East Anglia staff members drawn from all levels. The final version was prepared based on their comments about clarity, ability to answer, and overall length. The questionnaire is presented in Appendix 1 (www.intres.com/journals/suppl/appendix_palutikof.pdf).

We wished to explore whether regional differences would affect the responses to the questionnaire. We hypothesised that the wetter, cooler climate of northern Britain would generate different responses to those from the warmer, drier south (Tables 1 and 2). This interest is in line with studies by, for example, Ader (1995) and Shanahan \& Good (2000), who found a link between local temperature and frequency of attention to climate issues. Berk \& Schulman (1995), in a survey of public 'willingness-to-pay' to prevent various climate scenarios occurring, found that respondents were more motivated by temperature change than by precipitation change, and hypothesised that this might be due to the climate of Southern California, where the survey took place.

Two thousand copies of the questionnaire were sent out in late September/early October 1998: 1000 to addresses in southern England and 1000 to addresses in central and southern Scotland (Fig. 1). We employed a survey company to draw the sample of addresses, based upon our requirement of 1000 in England and 1000 in Scotland. We specified the postcode districts (there are approximately 3000 postcode districts in the UK) from which the samples should be drawn, as

Table 2. Mean daily temperature $\left({ }^{\circ} \mathrm{C}\right), 1961-1990$ average, for Edinburgh and Glasgow (shown as 'Scotland') and central Enland temperature (CET) (The Scottish Office 1998, Table 10C1, Climatic Research Unit, University of East Anglia, Norwich)

\begin{tabular}{|lcccccccccrrr|r|}
\hline & Annual & J & F & M & A & M & J & J & A & S & O & N & D \\
\hline Scotland & 8.7 & 3.6 & 3.6 & 5.4 & 7.3 & 10.3 & 13.2 & 14.7 & 14.5 & 12.4 & 9.7 & 5.6 & 4.1 \\
CET & 9.5 & 3.8 & 3.8 & 5.7 & 7.9 & 11.2 & 14.1 & 16.1 & 15.8 & 13.6 & 10.6 & 6.5 & 4.6 \\
\hline
\end{tabular}




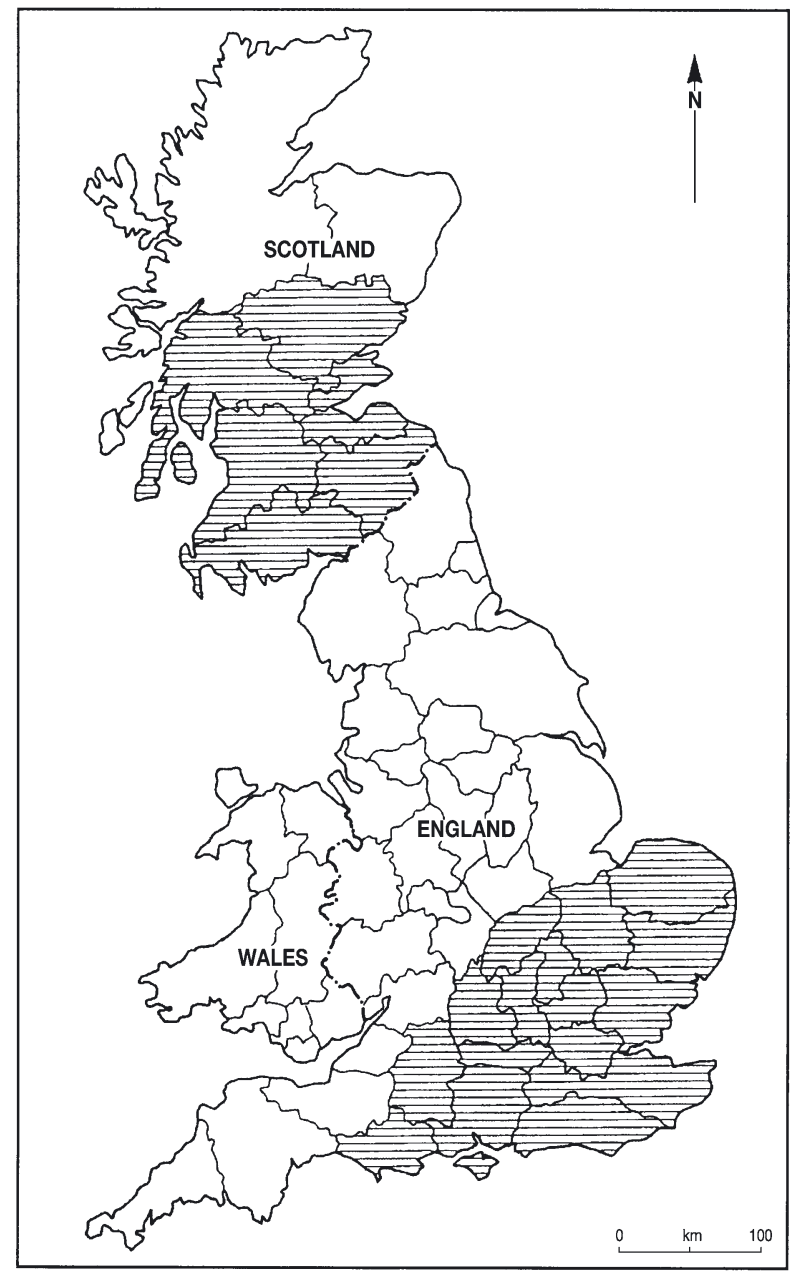

Fig. 1. Geographical location of the survey sample regions

shown in Fig. 1. The samples were chosen to be broadly similar in the sense that both are predominantly urban, built-up environments. Differences which might emerge between the 2 regions could therefore be more firmly ascribed to climatic, possibly cultural, differences. The sample of addresses was drawn by taking equal numbers of randomly selected addresses from each postcode district within the 2 target locations. The addresses were supplied as an electronic list, and we sent out the questionnaires to these addresses. A total of 295 questionnaires were completed and returned. Note, however, that in the tables and text which follow, the sample size is not always 295, due to missing responses.

The percentage responses to each question are inserted in the questionnaire in Appendix 1. Of the valid responses, 57\% were from England and $43 \%$ were from Scotland, $45 \%$ were males and $54 \%$ were females ( $1 \%$ unknown). When compared to the under- lying demographic structure, there is no evidence of a gender bias in the survey sample for England and Scotland $\left(\chi^{2}=2.20\right.$ and 0.36 respectively, $\left.\mathrm{p}<0.05\right)$. In addition, with the exception of those aged 55 to $64 \mathrm{yr}$, for which there was an over-representation relative to the underlying population, a $\chi^{2}$ test revealed no evidence of an age bias. Attempting to control for the age bias in the 55 to $64 \mathrm{yr}$ cohort may have introduced additional errors, and we therefore decided to leave the responses unadjusted (an approach that was adopted by Bord et al. 1998). A report summarising the results of the survey was offered to respondents, and $46 \%$ requested (and were supplied with) a copy, giving an indication of the level of general interest in the topic.

\section{LIMITATIONS TO THE STUDY}

There are several potential limitations or caveats that may have affected the questionnaire results:

\subsection{Response rate}

The response rates reported in other studies examining the perception of climate change have varied. Some studies have high response rates of over $60 \%$ (e.g. Degaetano 1999), for others the response rates are a more modest 50 to $60 \%$ (Berk \& Schulman 1995, Bord et al. 1998, Berk \& Fovell 1999). Yet, for some surveys the response rate has been less than $50 \%$. For example, Degaetano (1999) received only $35 \%$ of the surveys sent to golf-course superintendents, and Seacrest et al. (2000) reported that only $10 \%$ of the surveys distributed at a groundwater conference were completed and returned. The response rate for some surveys has not been documented, and only the sample size is quoted (e.g. Harrison et al. 1996, González \& de Silveira 1997, Gowda et al. 1997). The low response rate in this present survey $(15 \%)$ is a cause for concern, since it may have given rise to some selection bias. However, this is a conservative estimate, since a number of the surveys were undeliverable because, for example, people had moved away. In total, 295 questionnaires were returned. Since one of our key objectives was to compare the perception of 2 different geographic regions, and there was no evidence to suggest that the selection bias varied on a regional basis, the survey provides valid comparative sample data. However, caution is required in the interpretation of results relating to the complete data set, since these may represent a more well-informed section of the general public with an interest in climatic or environmental issues. 


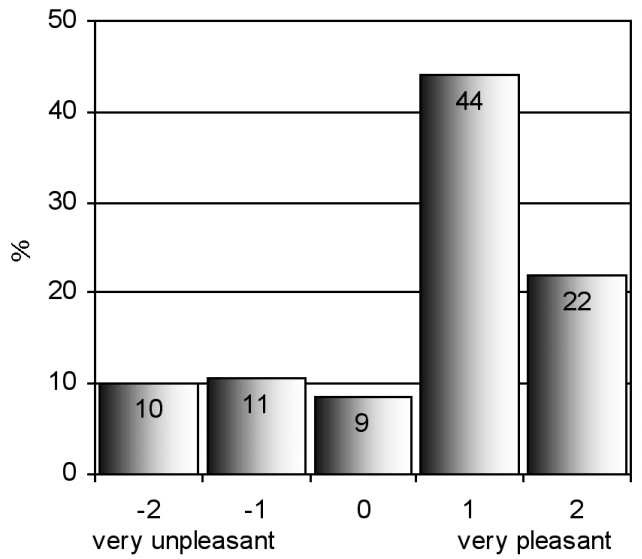

Fig. 2. Perceived overall impact of hot dry summers becoming more common in future

\subsection{Sampling bias}

As shown in Section 1.3, biases in gender are small and not significant, but there is a significant overrepresentation of the 55 to $64 \mathrm{yr}$ age group. No attempt has been made to adjust because of the risk of introducing additional inaccuracy.

\subsection{Social-desirability bias}

There may be a tendency for a respondent to overemphasise their environmental concern, as socially desirable responses are expressed in order to be viewed as a respectable citizen (Sterngold et al. 1994). Recall of behavioural changes may also be affected by this desire to be seen as a 'good' citizen.

\subsection{Leading questions}

The lists of potential impacts provided in the questionnaire could be leading and may have neglected aspects important to the respondents. Opportunity was provided for the respondents to note additional aspects not listed in the questionnaire. However, few additional factors were highlighted. These generally related to employment or hobbies: for example, people with the responsibility of maintaining cricket pitches or bowling greens.

\subsection{Memory}

Although many respondents failed to correctly identify years with extremely warm summers/winters, this is of little importance to the exercise, since we are trying to identify the generic response to seasonal extremes. However, it is possible that there were difficulties in remembering exactly how the extreme weather affected everyday activities.

Bearing in mind the potential bias in responses due to social desirability, memory and failure to respond, this study provides useful and unique data on the perception of seasonal extremes and climate change in 2 climatically contrasted areas of the UK.

\section{PERCEPTION OF SEASONAL EXTREMES AND CLIMATE CHANGE}

An individual's perception of seasonal extremes in general may affect the way they view climate impacts on everyday life and hence their likely response to the prospect of climate change. The questionnaire therefore commenced with a question on this topic (Appendix 1, Question 1). Most people (66\% of respondents) prefer unusually warm weather to unusually cold weather and think that the prospect of hot and dry summers being more common in the future (Question 15A) is either pleasant or very pleasant $(66 \%)$ (Fig. 2). However, this view is tempered by the finding that most people also think that the prospect of global warming (Question 19) is either worrying (39\%) or very worrying $(29 \%)$. This response seems to indicate an awareness of the potentially wider implications of climate change for policy and the national good, while at a personal level viewing hotter summers as intrinsically enjoyable in a temperate environment. Hedonistic attitudes and concerns for the future global prospect are not mutually exclusive.

\section{IMPACTS OF SEASONAL EXTREMES ON EVERYDAY LIFE}

\subsection{Unusually hot dry summers}

Respondents were asked to recall a recent hot and dry summer in the UK (Appendix 1, Question 2). With this summer in mind they were asked about the impact of the extreme weather on 9 different aspects of their everyday life (personal comfort; activities at work, college or school; housework; outdoor leisure activities; health; everyday travel; air quality; water use; and home-energy use). For each aspect, respondents were asked to record their perception of the impact on an integer scale ranging from -2 (very unfavourably affected) to 2 (very favourably affected). The options 'can't remember' and 'doesn't apply' were also available. Three clear positive effects of unusually hot dry summers were noted: more outdoor leisure $(66 \%$ 


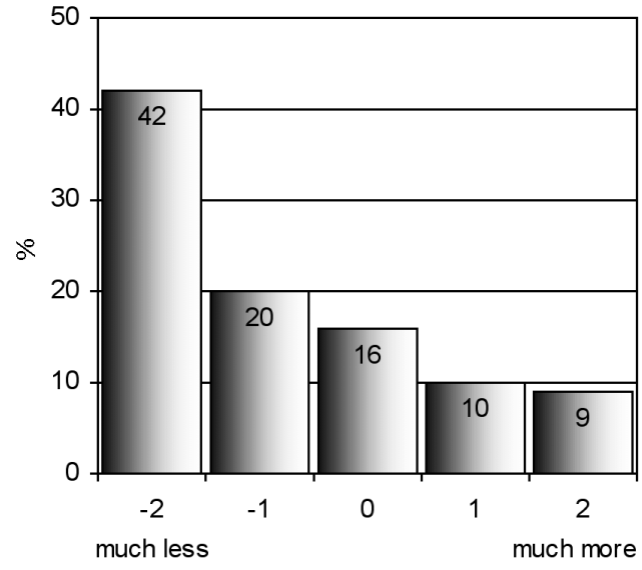

Fig. 3. Perceived impacts of the hot dry summer on energy use

respondents), better health (54\%), and lower energy use $(62 \%)$. Feelings of discomfort were recorded with respect to activities at home ( $42 \%$ respondents), activities at work $(44 \%)$ and overall with respect to 'personal comfort' $(41 \%)$. Negative impacts were seen to have emerged with respect to air quality ( $45 \%$ respondents) and water use $(61 \%$ reported much greater use). Note that the domestic water supply in the UK may be metered or fixed cost, with a move towards metering in new properties.

The responses for energy use in summer are shown in Fig. 3. A clear majority of respondents claim to have used less energy in an unusually hot summer, and $42 \%$ think that they used much less. Little energy is normally used for space heating in the summer; therefore, it is not clear where any large reductions in energy use could come from. Possibly fewer cooked meals and spending more time outdoors in the evening account for this sense of reduced energy use. The use of air-conditioning is still not common in the UK. During the hot summer recalled, only $13 \%$ of the sample owned air-conditioned cars, and only $9 \%$ spent most of their time in an air-conditioned indoor environment.

\subsection{Unusually warm winters}

Similarly, respondents were asked to recall an unusually warm winter in recent years (Appendix 1, Question 20) and were questioned about its impact on 9 aspects of everyday life (personal comfort; everyday travel; outdoor leisure activities; winter sports; winter 'atmosphere'; health; air quality; home-energy use; and pests [insects, mice, etc.]). The overall impact was regarded as positive. The only clear negative effects were seen as an unfavourable impact on winter sports,

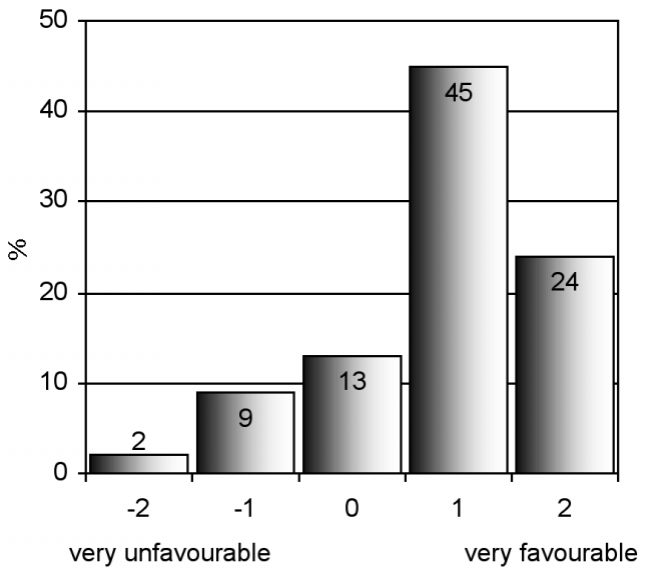

Fig. 4. Perceived impacts of the unusually warm winter on personal comfort

and a greater numbers of pests. Of the positive aspects, $69 \%$ of respondents believe that warm winters have a favourable impact on personal comfort (Fig. 4). Respondents were asked to select which aspect in the list of 9 was the most important to them; 32\% chose personal comfort, $23 \%$ chose health, and $13 \%$ of the respondents chose home-energy use. These are similar to those aspects of everyday life selected as being the most important impacts of hot dry summers, namely personal comfort $(29 \%)$ and health $(21 \%)$. The exception is home-energy use (only $4 \%$ for hot dry summers, a statistically significant difference $\left.\left[\chi^{2} ; \mathrm{p}<0.05\right]\right)$.

\section{PERCEIVED IMPACTS FOR THE COUNTRY AS A WHOLE}

An individual's perception of the impacts of extremes on his or her everyday life may differ from the perceived impacts for the country as a whole. Therefore, respondents were asked (Appendix 1, Question 13) to consider the national implications of the recalled hot dry summer for 11 environmental, social and economic concerns: hospitals and medical services, agriculture, water supply, road traffic, air quality, countryside and wildlife, productivity at work, leisure and tourism, the UK economy, outdoor fires, and crime and public disorder. The responses are shown in Fig. 5. Note that, in this figure, an unfavourable impact on fires and crime means that more incidents occurred. The impact for the vast majority of individual sectors was regarded as negative. Only leisure and tourism activities were clearly identified as gaining from a hot summer. Although $51 \%$ of respondents also believed that the UK economy was favourably affected, this category recorded a very high percentage of missing $(12 \%)$ and indetermi- 


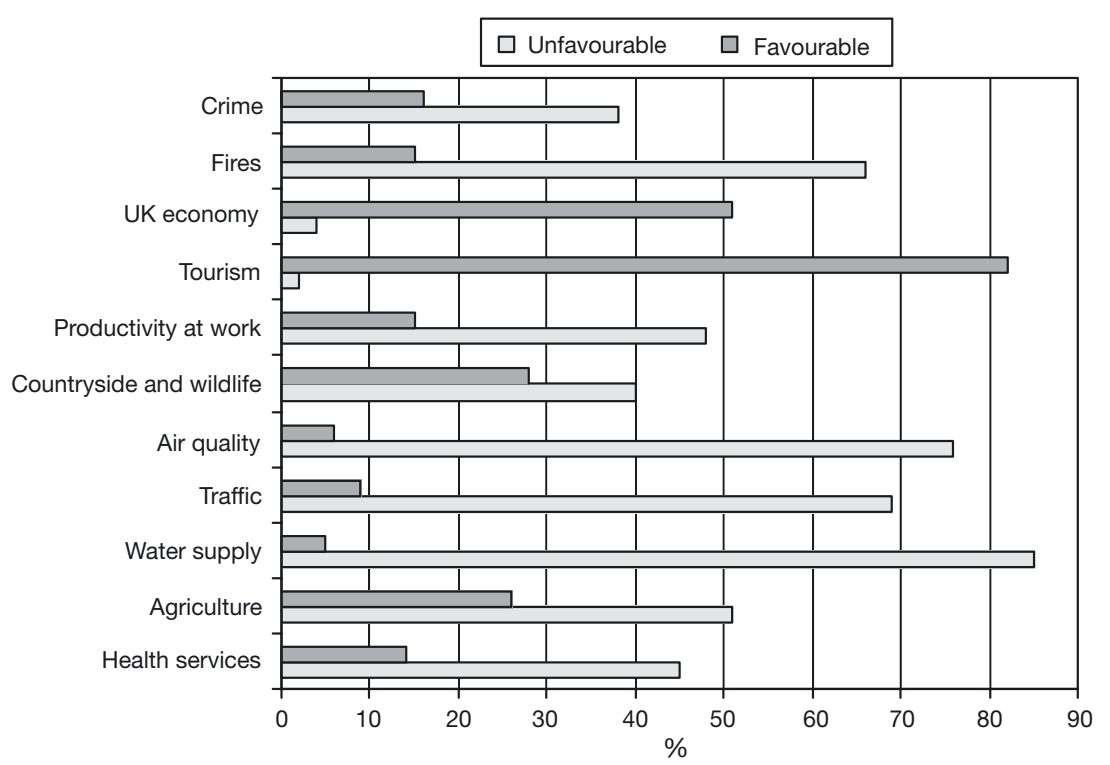

Fig. 5. Perceived impacts of the hot dry summer weather on 11 activity and environmental categories, for the country as a whole

or 2 in Question 2A (unfavourable) and respondants ticking Box 4 or 5 (favourable) exceeds $20 \%$ for agriculture, and health services. That is, people who experienced discomfort in their recalled hot summer are more likely to perceive the impacts for the country as a whole as unfavourable, whilst those whose personal comfort was improved are more likely to perceive the countrywide impacts as favourable.

\section{THE PROSPECT OF HOT DRY SUMMERS BECOMING MORE COMMON}

Finally, with respect to impacts, we asked people to think about a future climate in which hot dry summers become more common. The first question in this section (Appendix 1, Question 14) addressed the perceived likelihood of this. A majority of respondents $(58 \%)$ think it

nate $(26 \%$ chose the middle option, 5\% could not remember and $3 \%$ said it did not apply) responses (see Appendix 1). The areas and activities which most respondents considered to be negatively impacted were water supply (85\% of respondents), air quality $(76 \%)$, road traffic $(69 \%)$, fire incidence $(66 \%)$ and agriculture (51\%).

It was considered possible that responses in this section might be related to personal experience of the recalled hot and dry summer. We therefore classified the responses to Question 13 by the responses to Question 2A, which asked people to rate how their personal comfort was affected by the especially hot and dry summer they recalled. The results are shown in Fig. 6. Looking at the respondents giving a favourable response in Question 13, we find predominately negative differences between those who said they experienced personal discomfort in Question 2A (ticking Box 1 or 2) and those who experienced their recalled hot summer favourably with respect to personal comfort (ticking Box 4 or 5). Particularly large contrasts ( -30 to $-20 \%$ ) are seen for productivity at work, countryside and wildlife, agriculture and health services. Of those giving an unfavourable response in Question 13, the differences between the respondants ticking Box 1 likely that hot dry summers will be more common in future, but only $29 \%$ of all respondents found the prospect of more frequent hot summers alarming.

Respondents were presented with lists of potential positive (Question 16) and negative (Question 17) impacts of more frequent hot and dry summers and were asked to select which applied to them (Fig. 7). When

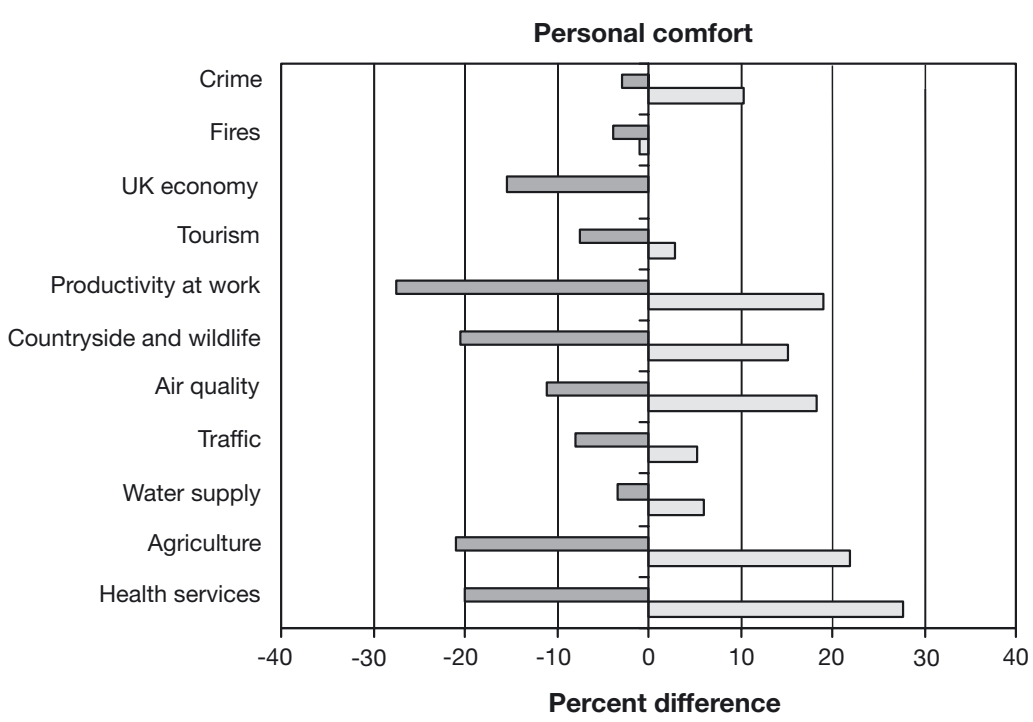

Fig 6. Relationships between perceived impacts of the hot dry summer weather and personal comfort. Bars show percentage difference between respondants ticking Box 1 or 2 in Question 2A and respondants ticking Box 4 or 5. Dark bars: respondants giving a favourable-impact response in Question 13. Light bars: respondants giving an unfavourable-impact response in Question 13 


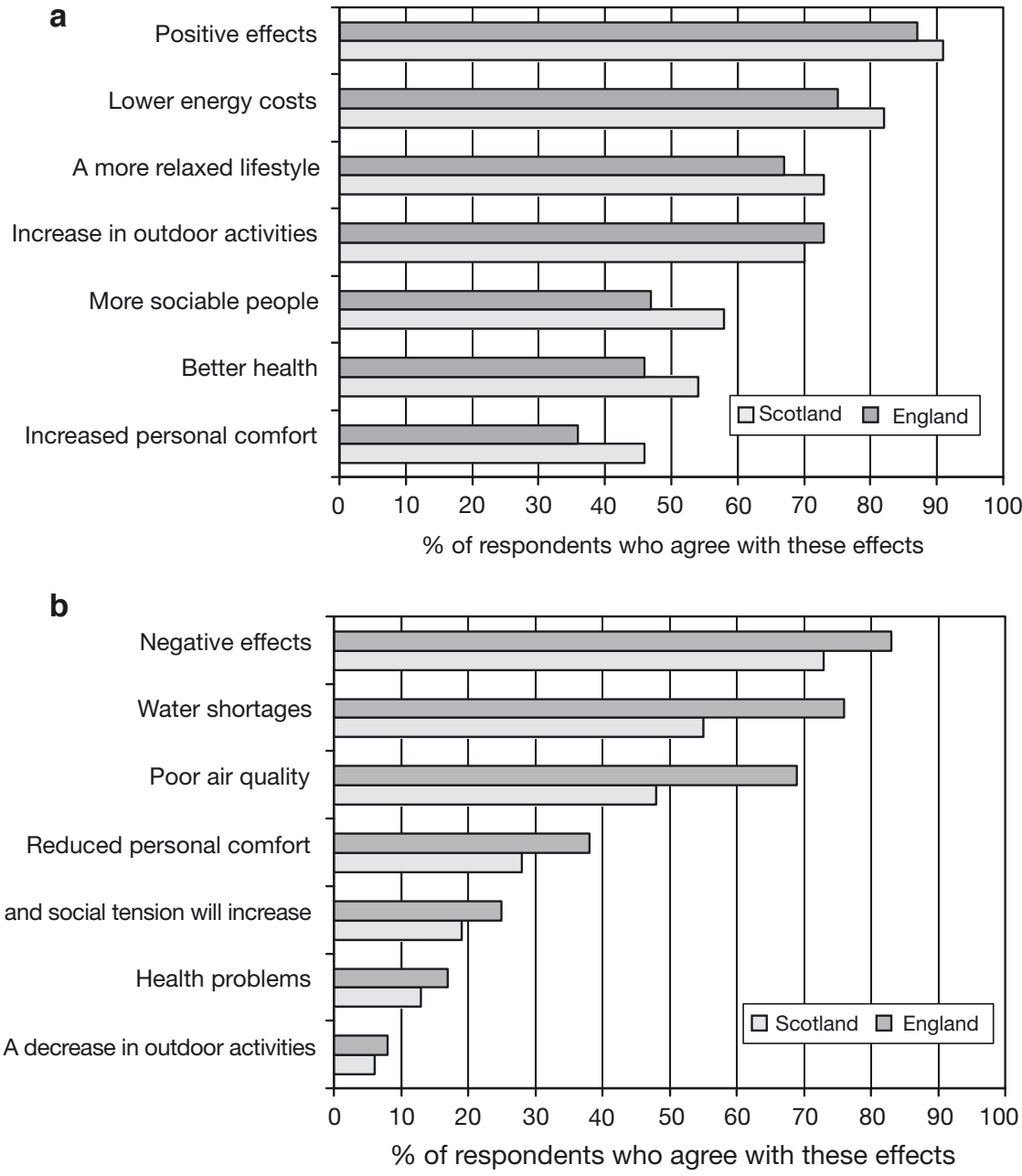

Fig. 7. Percentage of respondents agreeing that (a) positive and (b) negative impacts would result from more hot dry summers in future

directed to assess whether this was a short-term or permanent adaptation and whether they would make any permanent changes to their lifestyle if hot dry summers were more common in the future.

\subsection{Short-term responses as a result of one unusually hot dry summer}

Respondents were asked whether, during the hot dry summer they recalled, they changed their mode of transportation (Question 5), their use of leisure facilities (Question 6), or their holiday plans (Questions 7-10). For transport, respondents were asked to record any change in use with respect to public transport, private car, motorbike/scooter, bicycle and walking. We might have expected that cars would have been used somewhat less in an extremely warm period, especially given the low availability of airconditioned vehicles in the UK. However, on the whole, people did not change their use of the car: $21 \%$ used the car less, $19 \%$ more, and for $41 \%$ there was no change. In contrast, walking and cycling were reported to be more popular as a result of the extremely hot summer: $58 \%$ said they walked more (Fig. 8), and 22\% claimed to have used their bicycle more often than in an average summer

asked whether, overall, there would be any positive effects, $85 \%$ of respondents answered in the affirmative, and, when asked whether there would be any negative effects, $74 \%$ respondents said there would be. Of the positive effects, most people thought that there would be lower energy costs $(78 \%)$, an increase in outdoor activities $(71 \%)$ and a more relaxed lifestyle (69\%). The negative effects selected by a majority were water shortages (66\%) and poor air quality (59\%). The responses indicate an ability to recognise that climate change presents both threats and opportunities. This ability has been detected in other surveys (for example, Jordan et al. 2000).

\section{RESPONSE BEHAVIOURS AND ADAPTATION}

The degree to which respondents modified their behaviour in response to recent extreme weather events was used as a measure of adaptation. Questions were (although for $64 \%$ of respondents this question didn't apply or the data were missing). Since use of the car did not change, this implies more outdoor recreational activity, and indeed this is confirmed by the other short-term changes in lifestyle identified in Question 6: greater use of the countryside $(67 \%)$, outdoor restaurants $(55 \%)$, beach $(39 \%)$ and outdoor sports $(31 \%)$; reduction in use of indoor restaurants and bars (25\%), and theatres, cinemas and museums (24\%).

A series of more specific questions was asked about changes to holiday plans during the hot dry summer. Any change in the number of day trips and short trips or weekend breaks were noted on a 5-point scale (from 'many fewer' to 'many more'). In addition, respondents were asked whether they had altered their main summer holiday plans in terms of location, timing or length. The sensitivity of holiday planning during the hot and dry summer appears to vary according to the length of trip. It was more common for people to report a change in the 


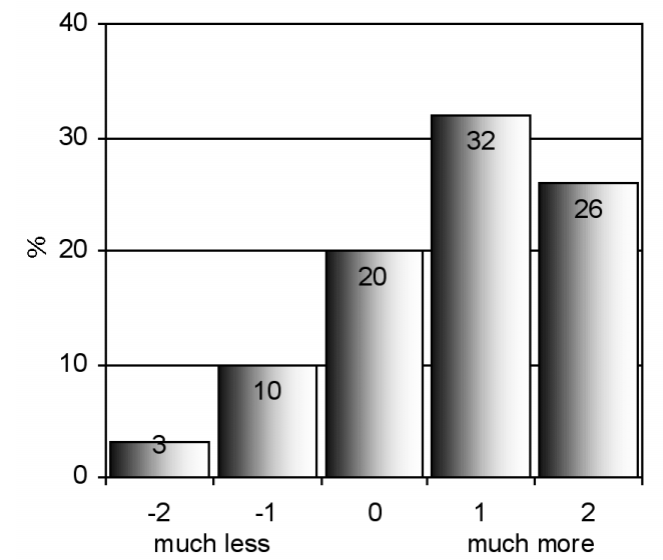

Fig. 8. Change in walking habits during the especially hot dry summer weather

number of day trips taken, rather than in the number of longer holiday breaks. For example, we find that $54 \%$ of respondents took more day trips during the hot summer, while $33 \%$ of respondents took more weekend or short breaks. Only $12 \%$ claimed to have altered their main holiday arrangements during the hot summer. This is not surprising, since people generally book their main holiday well in advance, and arrangements are much less flexible than for short breaks or day trips.

\subsection{Permanent adaptation following one hot and dry summer}

Respondents were asked whether they made any permanent changes to their lifestyle because of the hot and dry summer they recalled, and a list of possi- ble activities was presented (Question 12 and Fig. 9a). Approximately half of the respondents claimed to spend more time outdoors and eat more fruit and salad as a result of their experience of the hot dry summer. Almost one-third try to avoid the sun more, a quarter use less water, and one-fifth use the car less. It is perhaps surprising to find such a large proportion of people claiming to have made permanent changes to their lifestyle because of one unusually hot dry summer. No doubt lifestyle changes are additionally influenced by other factors, such as media interest in climate change, publicity campaigns to conserve water, and health campaigns regarding the dangers of melanoma.

\subsection{Planned adaptation if hot dry summers become more common in future}

As expected, the proportion of respondents believing that they would make permanent changes in their lifestyle if hot dry summers become more common (Question 18 and Fig. 9b) was considerably higher than the proportion that made permanent changes following their recalled extremely hot summer. For example, if the frequency of hot dry summers increases in the future:

- $72 \%$ of respondents said they would spend more time outdoors, compared to just $48 \%$ who made a permanent change as a result of one extreme summer,

- $52 \%$ said they would use less water (compared to $26 \%$ ),

- $38 \%$ said they would grow different plants in their gardens (compared to $14 \%$ ),
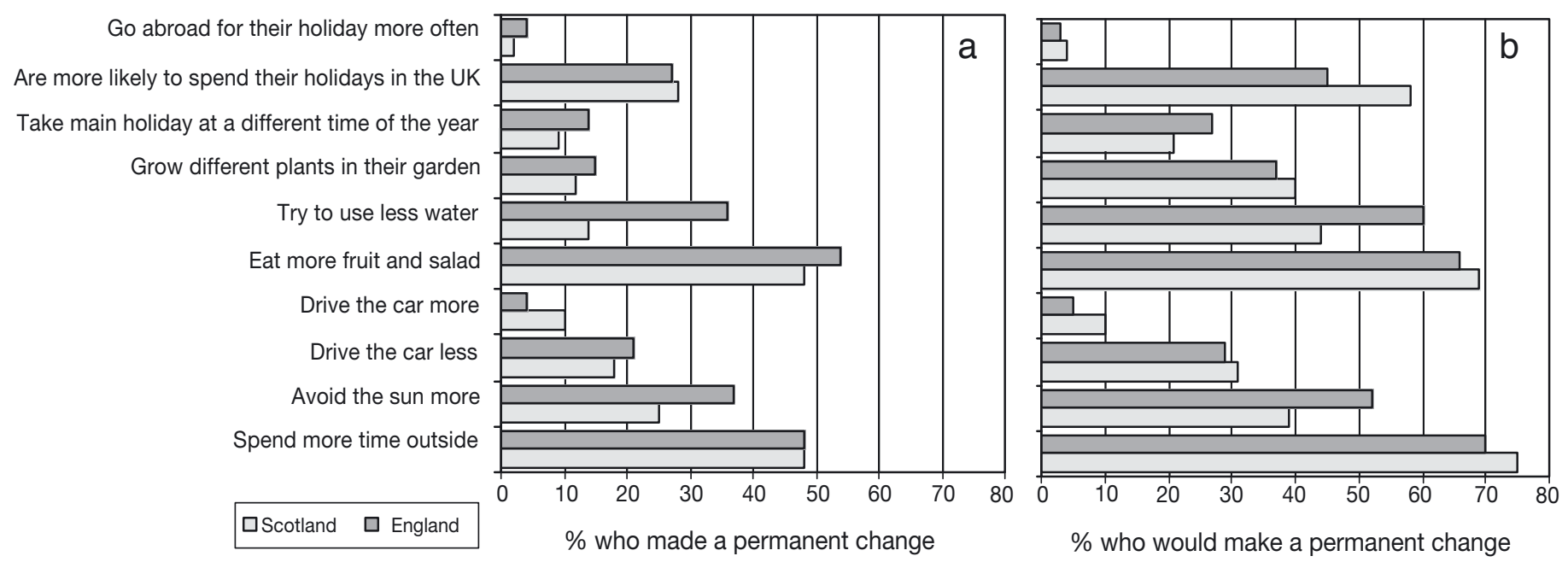

Fig. 9. Percentage of respondents who (a) made permanent changes as a result of one hot dry summer and (b) would make permanent changes if hot dry summers became more common in the future 
Table 3. Planned activity changes for more common hot and dry summers in future, according to age (yr), gender, and country of residence. Percentages are of the number of people in each category who state they would make the change (values in bold are the largest differences in each sub-category, where the difference is $\geq 10 \%$ )

\begin{tabular}{|c|c|c|c|c|c|c|c|c|c|c|c|}
\hline Category & Count & $\begin{array}{c}\text { More } \\
\text { time } \\
\text { outdoors } \\
(\%)\end{array}$ & $\begin{array}{l}\text { Avoid } \\
\text { sun } \\
(\%)\end{array}$ & $\begin{array}{l}\text { Drive } \\
\text { car } \\
\text { less } \\
(\%)\end{array}$ & $\begin{array}{l}\text { Drive } \\
\text { car } \\
\text { more } \\
(\%)\end{array}$ & $\begin{array}{c}\text { Eat fruit } \\
\text { and } \\
\text { veg. } \\
(\%)\end{array}$ & $\begin{array}{c}\text { Use } \\
\text { less } \\
\text { water } \\
(\%)\end{array}$ & $\begin{array}{c}\text { Different } \\
\text { plants } \\
(\%)\end{array}$ & $\begin{array}{c}\text { Holiday } \\
\text { timing } \\
(\%)\end{array}$ & $\begin{array}{c}\text { Holiday } \\
\text { in } \\
\text { UK } \\
(\%)\end{array}$ & $\begin{array}{c}\text { Holiday } \\
\text { abroad } \\
(\%)\end{array}$ \\
\hline \multicolumn{12}{|l|}{ Age } \\
\hline $16-24$ & 18 & 72 & 44 & 22 & 6 & 72 & 61 & 28 & 17 & 33 & 17 \\
\hline $25-34$ & 52 & 71 & 38 & 33 & 10 & 62 & 42 & 17 & 33 & 46 & $\mathbf{0}$ \\
\hline $35-44$ & 64 & 68 & 47 & 30 & 3 & 58 & 45 & 33 & 25 & 66 & 3 \\
\hline $45-54$ & 58 & 76 & 40 & 29 & 10 & 64 & 57 & 47 & 19 & 47 & 5 \\
\hline $55-64$ & 41 & 76 & 44 & 32 & 7 & 85 & 58 & 51 & 37 & 56 & 0 \\
\hline $65-74$ & 38 & 74 & 50 & 34 & 5 & 68 & 63 & 39 & 24 & 50 & 5 \\
\hline+75 & 18 & 78 & 78 & 17 & 11 & 78 & 56 & 17 & 0 & 33 & 0 \\
\hline \multicolumn{12}{|l|}{ Gender } \\
\hline Male & 132 & 75 & 46 & 28 & 11 & 66 & 47 & 39 & 24 & 52 & 4 \\
\hline Female & 157 & 70 & 46 & 32 & 4 & 68 & 57 & 38 & 25 & 50 & 3 \\
\hline \multicolumn{12}{|l|}{ Country } \\
\hline England & 166 & 70 & 52 & 29 & 5 & 66 & 60 & 37 & 27 & 45 & 3 \\
\hline Scotland & 126 & 75 & 39 & 31 & 10 & 69 & 44 & 40 & 21 & 58 & 4 \\
\hline
\end{tabular}

- $50 \%$ said they would be more likely to spend holidays in the UK (compared to $27 \%$ ), and

- $66 \%$ said they would eat more fruit and salad (compared to $51 \%$ ).

\subsection{Characteristics influencing planned adaptations}

We explored the possibility that there are certain characteristics or opinions held by respondents that make it more likely they will plan to alter their activities if hot and dry summers become more common in the future. Age, gender and regional differences in likely adaptations to the hypothetical future climate are shown in Table 3. The absolute number for each subgroup is presented ('count') along with the percentage of people from this subgroup that would make an activity change. There are no large gender differences except with respect to water use: $57 \%$ of females would try to use less water compared with only $47 \%$ of males. When water use is analysed by age and by gender, we find by far the greatest contrast for the 35-44 yr age group (only $28 \%$ of men identify economies of water use, compared to $56 \%$ of women), followed by the 45-54 yr age group (48\% men compared to $64 \%$ women). The $75+\mathrm{yr}$ age group also shows strong differences $(42 \%$ of men compared to $83 \%$ of women), but the sample is small, just 12 men and 6 women. In general, it is the most economically active population, from 25 to $54 \mathrm{yr}$, which shows the greatest contrast between men and women in attitudes to water use. This age group is also most likely to have children living at home-women generally take greater day-to-day responsibilities for bringing up children and household management during these years, and therefore should have a greater understanding of domestic water consumption.

Responses with respect to planned adaptations are more dependent upon age difference than upon gender. These age-related differences appear linked to differences which can already be observed in the general population, and to choices which may be available to one age group but not to another. For example, the largest difference is with regard to sun avoidance: $78 \%$ of the most elderly cohort $(75+\mathrm{yr})$ would try to avoid the sun compared to only $38 \%$ of those aged $25-34$ yr. Observation suggests that older people normally avoid the sun to a greater extent than younger people, regardless of climate change. Other significant age-related differences in response $\left(\chi^{2} ; \mathrm{p}<0.05\right)$ are observed for driving the car less, eating more fruit and vegetables, growing different plants in the garden and taking the main holiday at a different time of the year. These are all choices important to and available to the older cohort, who may no longer have children living at home, and may be retired from work. Younger people with children living at home and in employment do not have the option to drive the car less, are constrained by school holidays in their choice of holiday dates, and have less time to devote to hobbies such as gardening. There are also large differences with respect to holiday decisions; $33 \%$ more people aged 35-44 yr are more likely to spend holidays in the UK than is the case for either the youngest or oldest cohorts.

Choice of proposed future activity/lifestyle change also varies according to the perception of the hot dry 
Table 4. Perception of present-day hot and dry summers and the planned activity changes for such summers becoming more common in future

\begin{tabular}{|c|c|c|c|c|c|}
\hline Statement & Response & Count & $\begin{array}{l}\text { Planned activity } \\
\text { change. I would... }\end{array}$ & Count & $\begin{array}{l}\% \text { of } \\
\text { response }\end{array}$ \\
\hline $\begin{array}{l}\text { The effect of the hot and dry summers } \\
\text { on outdoors activities was positive }\end{array}$ & $\begin{array}{l}\text { Agree } \\
\text { Disagree }\end{array}$ & $\begin{array}{r}210 \\
45\end{array}$ & $\begin{array}{l}\text { Spend more time } \\
\text { outdoors }\end{array}$ & $\begin{array}{r}176 \\
20\end{array}$ & $\begin{array}{l}84 \\
44\end{array}$ \\
\hline $\begin{array}{l}\text { More common hot and dry } \\
\text { summers would be... }\end{array}$ & $\begin{array}{l}\text { Pleasant } \\
\text { Very unpleasant }\end{array}$ & $\begin{array}{r}171 \\
28\end{array}$ & & $\begin{array}{r}107 \\
6\end{array}$ & $\begin{array}{l}63 \\
21\end{array}$ \\
\hline $\begin{array}{l}\text { As a result of the hot and dry summer, I } \\
\text { drive the car... }\end{array}$ & $\begin{array}{l}\text { Less } \\
\text { More }\end{array}$ & $\begin{array}{r}45 \\
188\end{array}$ & Drive the car less & $\begin{array}{l}39 \\
12\end{array}$ & $\begin{array}{r}87 \\
6\end{array}$ \\
\hline $\begin{array}{l}\text { For the country as a whole, the hot and } \\
\text { dry summer affected air quality... }\end{array}$ & $\begin{array}{l}\text { Favourably } \\
\text { Unfavourable }\end{array}$ & $\begin{array}{r}18 \\
223\end{array}$ & Drive the car more & $\begin{array}{r}4 \\
13\end{array}$ & $\begin{array}{r}22 \\
6\end{array}$ \\
\hline $\begin{array}{l}\text { In my everyday life the hot and dry } \\
\text { summer affected air quality... }\end{array}$ & $\begin{array}{l}\text { Favourably } \\
\text { Unfavourably }\end{array}$ & $\begin{array}{r}67 \\
131\end{array}$ & & $\begin{array}{r}12 \\
3\end{array}$ & $\begin{array}{r}18 \\
2\end{array}$ \\
\hline $\begin{array}{l}\text { During the hot and dry summer, I used } \\
\text { my car... }\end{array}$ & $\begin{array}{l}\text { More } \\
\text { Less }\end{array}$ & $\begin{array}{l}57 \\
59\end{array}$ & & $\begin{array}{r}10 \\
1\end{array}$ & $\begin{array}{r}18 \\
2\end{array}$ \\
\hline $\begin{array}{l}\text { More common hot and dry summers } \\
\text { would be... }\end{array}$ & $\begin{array}{l}\text { Unpleasant } \\
\text { Pleasant }\end{array}$ & $\begin{array}{l}28 \\
64\end{array}$ & $\begin{array}{l}\text { Try to avoid the sun } \\
\text { more }\end{array}$ & $\begin{array}{l}25 \\
11\end{array}$ & $\begin{array}{l}89 \\
17\end{array}$ \\
\hline $\begin{array}{l}\text { I live in England and believe more } \\
\text { common hot and dry summers is... }\end{array}$ & $\begin{array}{l}\text { Likely } \\
\text { Unlikely }\end{array}$ & $\begin{array}{r}113 \\
14\end{array}$ & & $\begin{array}{r}63 \\
3\end{array}$ & $\begin{array}{l}56 \\
21\end{array}$ \\
\hline $\begin{array}{l}\text { Hot and dry summers will become more } \\
\text { common in future. }\end{array}$ & $\begin{array}{l}\text { Likely } \\
\text { Unlikely }\end{array}$ & $\begin{array}{r}170 \\
35\end{array}$ & $\begin{array}{l}\text { Eat more fruit and } \\
\text { vegetables }\end{array}$ & $\begin{array}{r}128 \\
18\end{array}$ & $\begin{array}{l}75 \\
51\end{array}$ \\
\hline $\begin{array}{l}\text { More common hot and dry summers } \\
\text { would cause water shortages }\end{array}$ & $\begin{array}{l}\text { Agree } \\
\text { Disagree }\end{array}$ & $\begin{array}{r}195 \\
39\end{array}$ & Try to use less water & $\begin{array}{r}126 \\
11\end{array}$ & $\begin{array}{l}65 \\
28\end{array}$ \\
\hline $\begin{array}{l}\text { In the hot and dry summer I remember, } \\
\text { my water use was... }\end{array}$ & $\begin{array}{l}\text { Much less } \\
\text { Much more }\end{array}$ & $\begin{array}{r}37 \\
172\end{array}$ & & $\begin{array}{l}24 \\
90\end{array}$ & $\begin{array}{l}65 \\
52\end{array}$ \\
\hline The prospect of global warming is... & $\begin{array}{l}\text { Exciting } \\
\text { Worrying }\end{array}$ & $\begin{array}{r}19 \\
197\end{array}$ & $\begin{array}{l}\text { Grow different plants } \\
\text { in my garden }\end{array}$ & $\begin{array}{l}13 \\
70\end{array}$ & $\begin{array}{l}68 \\
36\end{array}$ \\
\hline
\end{tabular}

summer recalled, as shown in Table 4. For example, $84 \%$ of the respondents who agreed that the effects of the recalled hot dry summer on outdoors activities were positive would spend more time outdoors if such summers became more common in future, compared to only $44 \%$ of the respondents who disagreed. Furthermore, $63 \%$ of those respondents who thought that more common hot and dry summers would be pleasant would spend more time outdoors compared to only $21 \%$ of those who thought that the prospect of more common hot and dry summers would be unpleasant.

The variations in response to the proposed adaptations for different subgroups of the sample population appear consistent. In the example of water use in Table 4, we observe that people are more likely to say they would use less water in future if they believe a hot and dry summer causes water shortages and if during their recalled extreme season they used less water. In the example of car use, $7 \%$ of respondents said they would increase their car use if hot dry summers became more common. They were more likely to give this response if they believed that the recalled hot dry summer affected air quality favourably and if during the extreme summer they drove the car more. In a fur- ther example, a majority of those who view the prospect of more frequent hot dry summers in future as 'likely' and 'unpleasant' would try to avoid the sun more if hot and dry summers become more common in future.

\section{REGIONAL VARIATION IN THE RESPONSE TO CLIMATE EXTREMES}

\subsection{Impacts on everyday life}

For some aspects of everyday life the responses from Scotland and England showed clear differences. These are statistically significant $\left(\chi^{2} ; \mathrm{p}<0.05\right)$ for 2 responses. First, with respect to air quality, $52 \%$ of English respondents thought that the hot summer had an unfavourable influence on air quality, while $20 \%$ believed there was a favourable effect; in Scotland, $37 \%$ perceive that the effect of the hot summer on air quality was unfavourable and $29 \%$ favourable. Second, in relation to outdoor leisure activities, $8 \%$ more people in Scotland than in England claimed the hot weather had a very favourable effect. Twelve percent 


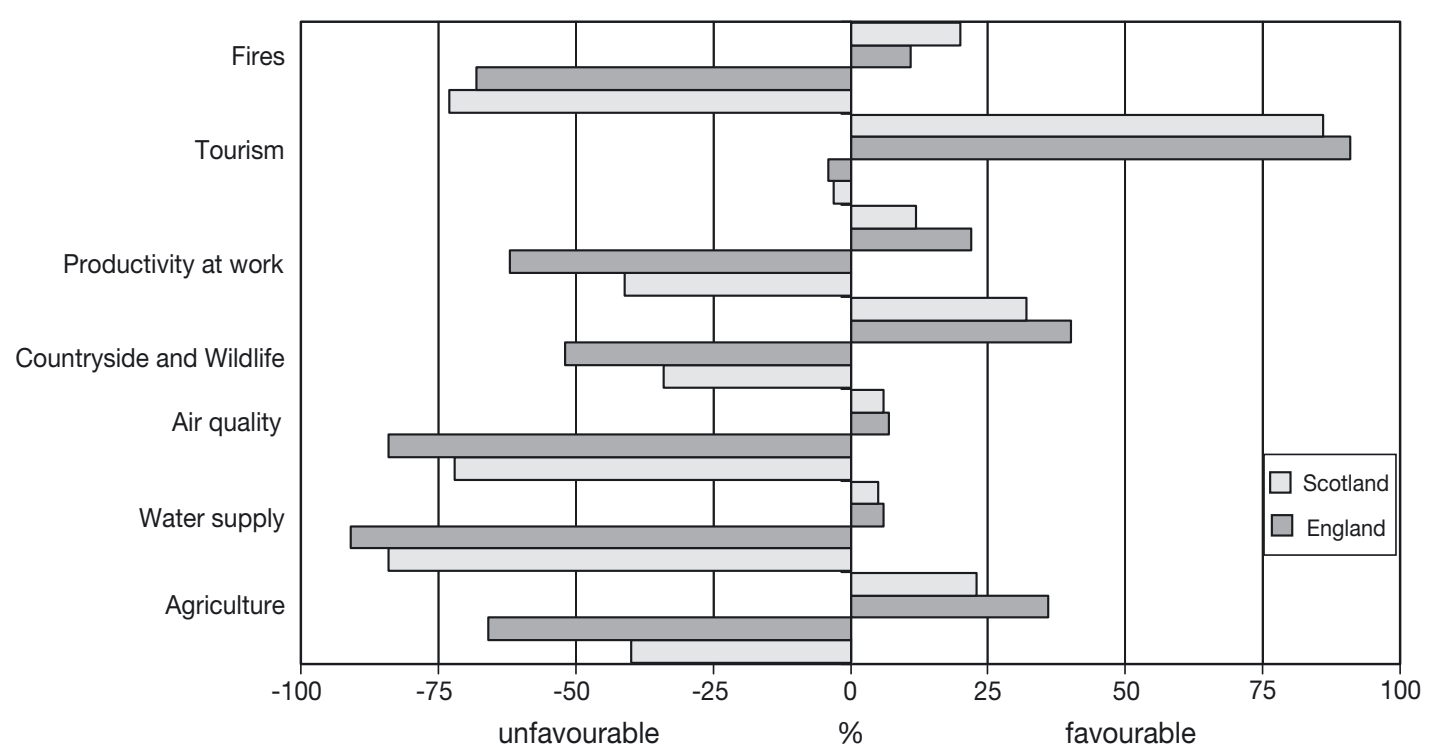

Fig. 10. Percentage of respondents who believe the sector impacts of the hot dry summer, for the country as a whole, were unfavourable or favourable

more people in England than in Scotland thought that hot weather had a very unfavourable effect on personal comfort.

There are 2 possible reasons for the differences in response between those living in England and Scotland. First, the average climate in Scotland is wetter and cooler than in England. Thus, the hot conditions in Scotland may have been more enjoyable because the temperature and precipitation extremes were lower in absolute terms than in England. For example, in 1995 during the 'high' summer (July and August) precipitation was $40 \mathrm{~mm}$ in south-east England and $122 \mathrm{~mm}$ in southern Scotland (Hulme 1997). Second, since hot dry conditions are less common (again in absolute terms) in Scotland, the negative aspects, such as water shortages, may be disregarded.

With respect to unusually warm winters, the largest differences in response between Scotland and southern England are in the perceived effects on winter sports and air quality. More people in Scotland believe that warm winters had an unfavourable effect on winter sports such as skiing: $31 \%$ compared to only $14 \%$ in England. A $\chi^{2}$ test for winter sports rejects the null hypothesis of no difference between English and Scottish respondents $(p<0.05)$. This is perhaps not surprising, given that Scotland has its own winter-sports resorts accessible for day trips from southern Scotland. There are no ski resorts in England, and so respondents would not relate winter sports to their own local experience. Overall, a majority of people thought that mild winters have a favourable influence on air quality, but the percentage was even higher in Scotland (43\%) than in England (33\%).

\subsection{Impacts for the country as a whole}

The dissimilarity in perception between respondents in Scotland and those in England is more apparent for questions related to the national good than for aspects of everyday life (Fig. 10). There are significant differences in response $\left(\chi^{2} ; \mathrm{p}<0.05\right)$ for 4 of the 10 aspects of the economy and environment presented in the questionnaire: agriculture, air quality, countryside and wildlife, and productivity at work. Impacts were perceived as more unfavourable in England than in Scotland for: productivity at work (difference of $21 \%$ ), countryside and wildlife (18\%), air quality (12\%) and agriculture $(22 \%)$.

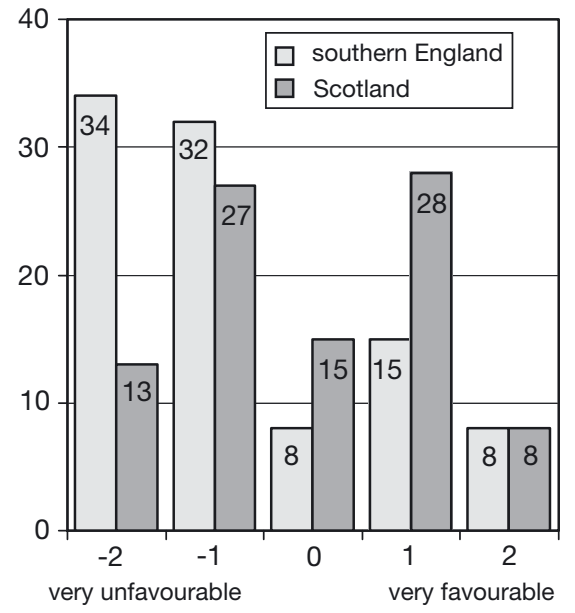

Fig. 11. Perceived impacts of the hot dry summer weather on agriculture, for the country as a whole 


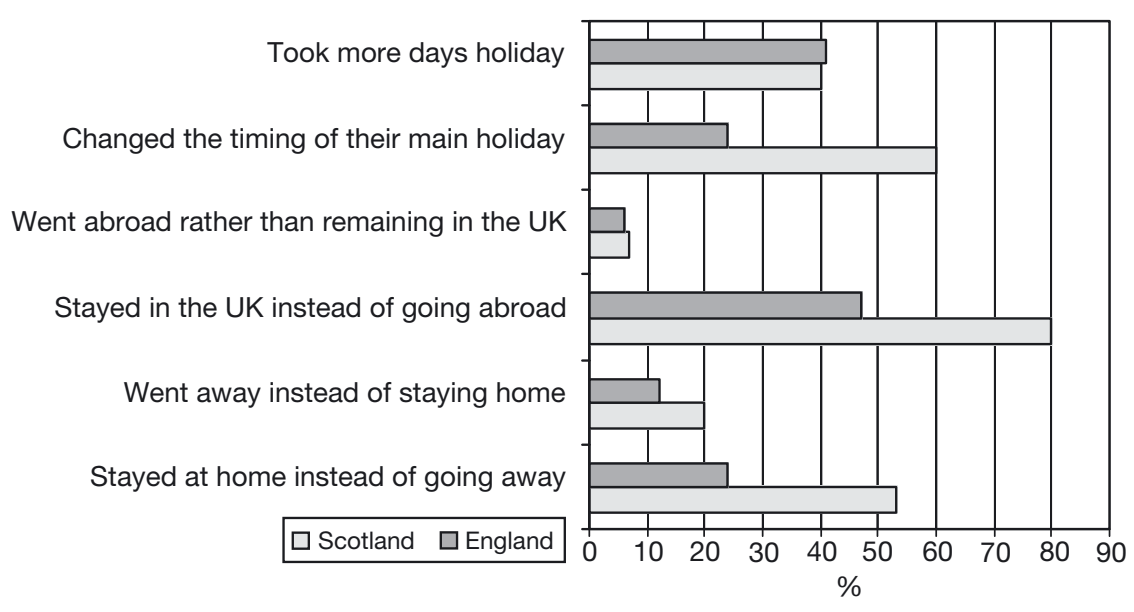

Fig. 12. Changes made to tourist-related activities (these are percentages of those who claimed to have altered their main holiday) because of the hot dry summer

\subsection{Responsive behaviour resulting from a recent extreme season}

In terms of short-term behavioural modifications during the unusually hot dry summer, the greatest difference between those living in Scotland and those living in southern England was found for tourism. In Scotland, $62 \%$ of the respondents took more day trips during the hot summer, compared to $46 \%$ in England. There was also substantial regional variation among those who altered their main holiday plans (Fig. 12). More people in Scotland than in England stayed at home instead of going away (53\% in Scotland and $24 \%$ in England) or stayed in the UK instead of going abroad (80\% in Scotland and $47 \%$ in England). There were also

The greatest difference in opinion was for agriculture (Fig. 11). The majority (66\%) of English respondents believed that agriculture was unfavourably affected by the hot summer. In Scotland almost as many respondents believed that the impact was positive $(36 \%)$ as believe it was negative $(40 \%)$. It is likely that these differences in perception are due to regional contrasts in climate (Hulme 1999b) and agricultural practices. In southern England, water is a limiting factor for a number of crops grown and present-day temperatures are at or close to the optimum. Further north, however, waterlogging and low sunshine hours can be problems, so that unusual warmth and sunshine are likely to be beneficial (MAFF 2000).

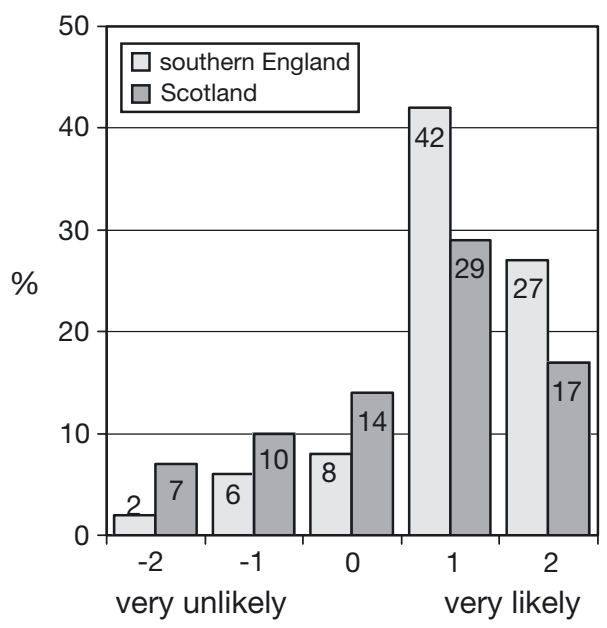

Fig. 13. Perceived likelihood of unusually hot dry summers becoming more common in future regional differences in walking habits: $36 \%$ of Scottish residents walked 'much more' compared to $22 \%$ in England, and only $4 \%$ of Scottish residents walked 'less' compared to $15 \%$ in England. Again, this difference appears related to differences in the age structure of the samples. Of those who responded to this question, $27 \%$ of the Scottish respondents were 55 or older, compared to only $15 \%$ of the English sample. Those who were able to, because they were retired or without dependent children, took the opportunity of the improved weather to walk more. For permanent adaptations that occurred following the extreme season, the greatest regional contrasts were for 'sun avoidance' and 'using less water': $12 \%$ more people in England than in Scotland have made a permanent change to avoid the sun, and $22 \%$ to use less water.

\subsection{Perceived impacts of more common hot summers and planned adaptation}

Responses related to a hypothetical future, in which hot and dry summers become more common, also differ between Scotland and England. A greater percentage of Scottish than English respondents agree with each positive effect listed (with the exception of outdoor activities, Fig. 7a), while a greater proportion of the English respondents agree with each negative impact (Fig. 7b). These differences are most striking for water shortages $76 \%$ of those in England agree with this negative impact compared to $55 \%$ of those in Scotland). A substantial contrast also exists for poor air quality (69\% of those in England agree with this negative impact compared to $48 \%$ of those in Scotland). This geographical difference is likely to be due to 
(1) the wetness of the Scottish climate and (2) recent heavily publicised water shortages in England (e.g. in the 1995 hot summer, see Haughton 1998). It is also interesting that a belief that hot dry summers will be more common in future is much more widely held in England (69\%) than in Scotland (46\%) (Fig. 13). This difference is significant $\left(\chi^{2} ; \mathrm{p}<0.05\right)$.

Regional differences persist in planned adaptation to the hypothetical future (Fig. 9). For example, only $14 \%$ of Scottish respondents claim they currently try to use less water following the hot summer, but this increases to $44 \%$ who would try to use less water should hot summers become more common. Amongst the respondents from England, 36\% made a permanent change to use less water and $60 \%$ would try to use less water if hot summers become more frequent in the future. These differences are most likely to be linked to the relative security of supply in the 2 regions. In England during the 1995 hot summer a number of water authorities had difficulty maintaining supply and hosepipe bans were widespread (Marsh 1996). Scotland did not experience the same problems. Other strong contrasts between the responses for Scotland and England are: avoiding the sun (an action that $13 \%$ more people in England than in Scotland would take) and taking the main holiday in the UK (13\% more people in Scotland than in England).

Generally, the impact of one hot and dry summer induces fewer permanent lifestyle changes in Scotland than in England. However, if such summers become more common in future, the proportion saying that they would make permanent changes in Scotland is almost the same as in England, and for some activities (spending more time outdoors and taking the main holiday in the UK), slightly higher.

\section{CONCLUSIONS}

This questionnaire sets out to explore self-reported perceptions of, and changing behaviour in response to, extreme seasonal weather, namely hot dry summers and unusually warm winters. It further asks people to explore, on the basis of their recollections, their thoughts regarding possible future warmer climates, how they might modify their behaviour in response to these longer-term and more persistent changes, and what the implications for the country at large might be.

This paper makes 2 specific and important contributions to the literature on public perceptions of climate change:

- In concentrating on the contrasts between responses from Scotland and England, it contributes to the cross-cultural perception studies defined as the second category in Section 1.1.
- In looking at how people adapted their behaviour in response to past seasonal extremes, and how they expect to adapt in future in response to climate change, the paper makes a unique contribution to the perception literature. Whereas most studies look at people's willingness to take action to mitigate climate change, few if any have explored adaptive responses.

Regional differences could generally be explained by differences in the climates and in the characters of hot summers in the 2 regions. Thus, the climate of southern Scotland is cooler and wetter, and extreme summers are less hot and dry, than in southern England. On this basis, we would expect Scottish respondents to experience hot summers as more pleasant than respondents in southern England. This turns out to be true. For example, $15 \%$ more people in England than Scotland perceive that a hot and dry summer has an unfavourable effect on air quality. For impacts on the country as a whole, English respondents were generally more likely to see the impacts as unfavourable, and the gap was particularly large for productivity at work ( $22 \%$ more of the English respondents perceived the impact on this as unfavourable), countryside and wildlife $(18 \%)$, and agriculture $(22 \%)$.

With respect to adaptive behaviour, people's reported actions generally fell into 1 (or more) of 3 categories:

- They chose, or would choose, to increase participation in activities which are pleasant and/or recreational. For example, people said that they used their bicycles more in their selected hot summer. However, their use of the car did not decline, implying that the cycling was an additional activity for recreational purpose.

- Their choices are part of general cultural trends, possibly something people are already advised to do for their health by the media and government. This includes staying out of the sun more and eating more fruit and vegetables.

- Their chosen actions are convenient/feasible within the framework of their day-to-day lives. Thus, when asked about their response to a hot as compared to a normal summer, a higher proportion of respondents took more day trips (52\%) than took more weekend/short holiday breaks (33\%), which in turn was a higher percentage than changed their main holiday plans (only $12 \%$ ). In general, older respondents were more likely to undertake adaptive responses, and we hypothesise that such actions as driving the car less, and changing the timing of the main holiday, are more feasible for the older generation without school-age children at home.

If hot summers were to become more common, people report that they would adapt to the situation in an 
altruistic way. We found this to be related mainly to water use. Thus, $52 \%$ respondents reported the intention to use less water if hot, dry summers became more common, an intention which is stronger amongst women than amongst men. However, we should note that when reporting their actions for a past hot summer, $61 \%$ respondents reported increased water use.

There is a clear need for further research effort on public perceptions of personal adaptations and behavioural responses to climate change. People in our survey perceived that more frequent hot and dry summers would be a pleasant experience for them personally (66\% of our respondents). More than half of our respondents identified greater sociability, increased outdoor activity, lower energy costs and a more relaxed lifestyle as positive benefits. There needs to be more detailed exploration of people's attitudes to climate change and its implications at a personal level. So long as people comprehend climate change as personally beneficial, despite identifying it as a problem for the UK as a whole, they are unlikely to consider the need for personal activities to mitigate climate change as important.

Acknowledgements. This work was funded by the Commission of the European Union, under contract ENV4-CT97-0448 'Weather Impacts on Natural Social and Economic Systems' (WISE).

\section{LITERATURE CITED}

Ader C (1995) A longitudinal study of agenda setting for the issue of environmental pollution. Journalism Mass Commun 72:300-311

Arnell NW (1996) Global warming, river flows and water resources. Wiley, Chichester

Berk RA, Fovell RG (1999) Public perception of climate change: a 'willingness to pay' assessment. Clim Change 41:413-446

Berk RA, Schulman D (1995) Public perceptions of global warming. Clim Change 19:1-33

Bord RJ, Fisher A, O'Conner RE (1998) Public perceptions of global warming: United States and international perspectives. Clim Res 11:75-84

Bord RJ, O'Connor RE, Fisher A (2000) In what sense does the public need to understand global climate change? Public Underst Sci 9:205-218

Brugge R (1992) Three years of warm weather over the British Isles, 1988-90. Weather 47:230-236

Cannell MGR, Pitcairn CER (eds) (1993) Impacts of the mild winters and hot summers in the United Kingdom in 1988-1990. Department of the Environment, HMSO, London

CCIRG (1996) Review of the potential effects of climate change in the United Kingdom. Climate Change Impacts Review Group, HMSO, London

Darier E, Jaeger CC, Kasemir B, Schüle R, Shackley S, Wynne B (1998) ULYSSES: Urban LifestYles, SuStainability and Integrated Environmental ASsessment. ULYSSES Working Paper, ULYSSES WP-98-1, Darmstadt University of Technology, Darmstadt
Degaetano AT (1999) A temporal comparison of drought impacts and responses in the New York City metropolitan area. Clim Change 42:539-560

Downing TE, Harrison PA, Butterfield R, Lonsdale KG (eds) (1999) Climate change, climate variability and agriculture in Europe: an integrated assessment. Research Report 21, Environmental Change Unit, University of Oxford, Oxford

Dukes M, Eden P (1997) Phew! What a scorcher: weather records and extremes. In: Hulme M, Barrow EM (eds) Climate of the British Isles: present, past and future. Routledge, London, p 262-293

Dunlap RE (1998) Lay perceptions of global risk-public views of global warming in cross-national context. Int Sociol 13:473-498

González LE, da Silveira P (1997) The people's attitudes towards global environmental phenomena: a case study. Clim Res 9:95-100

Gowda MVR, Fox JC, Magelky RD (1997) Student's understanding of climate change: insights for scientists and educators. Bull Am Meteorol Soc 78:2232-2240

Harrison CM, Burgess J, Filius P (1996) Rationalizing environmental responsibilities: a comparison of lay publics in the UK and the Netherlands. Global Environ Change 6: $215-234$

Haughton G (1998) Private profits - public drought: the creation of a crisis in water management for West Yorkshire. Trans Inst Br Geogr 23:419-433

Hulme M (1997) Climate. In: Palutikof JP, Subak S, Agnew MD (eds) Economic impacts of the hot summer and unusually warm year of 1995. University of East Anglia, Norwich, p 5-14

Hulme M (1999a) Air temperature in central England. In: Cannell MGR, Palutikof JP, Sparks TH (eds) Indicators of climate change in the UK. Climatic Research Unit and Centre for Ecology and Hydrology, Natural Environment Research Council, Edinburgh, p 6-7

Hulme M (1999b) Precipitation gradient across the UK. In: Cannell MGR, Palutikof JP, Sparks TH (eds) Indicators of climate change in the UK. Climatic Research Unit and Centre for Ecology and Hydrology, Natural Environment Research Council, Edinburgh, p 10-11

Hulme M and 11 others (2002) Climate change scenarios for the United Kingdom: the UKCIP02 scientific report. Tyndall Centre for Climate Change Research, School of Environmental Sciences, University of East Anglia, Norwich

IPCC (1998) The regional impacts of climate change; an assessment of vulnerability. A special report of IPCC Working Group II of the Intergovernmental Panel on Climate Change, Cambridge University Press, Cambridge

IPCC (2001) Impacts, adaptation, and vulnerability. Contribution of Working Group II to the Third Assessment Report of the Intergovernmental Panel on Climate Change, Cambridge University Press, Cambridge

Jones PD, Conway D (1997) Precipitation in the British Isles: an analysis of area-average data updated to 1995. Int J Climatol 17:427-438

Jordan A, Lorenzoni I, Hulme M, O'Riordan T, Turner K (2000) Co-evolutionary approach to climate impact assessment: a scenario-based study in the UK. CSERGE Working Paper 2000-01, Centre for Social and Economic Research on the Global Environment, University of East Anglia, Norwich

Kempton W (1991a) Lay perspectives on global climate change. Global Environ Change 1:183-208

Kempton W (1991b) Public understanding of global warming. Soc Natl Resourc 4:331-345

Kempton W (1997) How the public views climate change. 
Environment 39:12-21

Kramer KI, Friend AD, Leinonen I (1996) Modelling comparison to evaluate the importance of phenology for the effects of climate change on growth of mixed-species temperatezone deciduous forests. Clim Res 7:31-41

Krosnick JA, Holbrook AL, Visser PS (2000) The impact of the fall 1997 debate about global warming on American public opinion. Public Underst Sci 9:239-260

MAFF (2000) Climate change and agriculture in the United Kingdom. Report prepared for the UK Ministry of Agriculture, Fisheries and Food, MAFF Publications, London

Marsh TJ (1996) The 1995 UK drought-a signal of climate instability? Proc Inst Civil Eng-Water Maritime Eng J 118:189-195

Marsh TJ, Turton PS (1996) The 1995 drought-a water resources perspective. Weather 51:46-53

Martens P (1998) Health and climate change:modelling the impacts of global warming and ozone depletion. EarthScan, London

McMichael AJ, Haines A, Slooff R, Kovats S (eds) (1996) Climate change and human health. An assessment prepared by a Task Group on behalf of the World Health Organisation, World Meteorological Organization and United Nations Environment Programme. World Health Organization, Geneva

National Assessment Synthesis Team (2000) Climate change impacts on the United States: the potential consequences of climate variability and change. US Global Research Program, Washington, DC

National Statistics (2001) Regional trends. The Stationery Office, London

O'Connor RE, Bord RJ, Fisher A (1998) Rating threat mitigators: faith in experts, governments, and individuals themselves to create a safer world. Risk Anal 18:547-556

O'Connor RE, Bord RJ, Fisher A (1999) Risk perceptions, general environmental beliefs, and willingness to address climate change. Risk Anal 19:461-471

Parry ML (ed) (2000) Assessment of potential effects and

Editorial responsibility: Hans von Storch,

Geesthacht, Germany adaptations for climate change in Europe. The Europe ACACIA Project, Jackson Environment Institute, University of East Anglia, Norwich

Perron B, Vaillancourt JG, Durand C (2001) A global problem for a global movement? An exploratory study of climate change perception by green groups' leaders from Quebec (Canada) and Costa Rica. Soc Natl Resourc 14:837-855

Rudig W (1995) Public opinion and global warming. Strathclyde Papers on Government and Politics, No. 101, Department of Government, University of Strathclyde, Glasgow

Schellnhuber HJ, Enke W, Flechsig M (eds) (1994) The extreme summer of 1992 in Northern Germany. PIK Reports No. 2, Vol 4. Potsdam Institute for Climate Impact Research, Potsdam

Seacrest S, Kuzelka R, Leonard R (2000) Global climate change and public perception: the challenge of translation. J Am Water Resourc Assoc 36:253-263

Shanahan J, Good J (2000) Heat and hot air: influence of local temperature on journalists' coverage of global warming. Public Underst Sci 9:285-295

Stamm KR, Clark F, Eblacus PR (2000) Mass communication and public understanding of environmental problems: the case of global warming. Public Underst Sci 9:219-237

Sterngold A, Warland RH, Herrman RA (1994) Do surveys overstate public concerns? Public Opin Q 58:255-263

Stoll-Kleemann S, O'Riordan T, Jaeger CC (2001) The psychology of denial concerning climate mitigation measures: evidence from Swiss focus groups. Global Environ Change 11:107-117

Subak S (2000) Climate change adaptation in the UK water industry: managers' perceptions of past variability and future scenarios. Water Resourc Manage 14:137-156

The Scottish Office (1998) The Scottish abstract of statistics. General Statistical Service, Edinburgh

Ungar S (2000) Knowledge, ignorance and popular culture: climate change versus the ozone hole. Public Underst Sci 9:297-312

Submitted: June 8, 2002; Accepted: January 20, 2004

Proofs received from author(s): April 8, 2004 